\title{
Glucocorticoid Receptor as a Potential Target to Decrease Aromatase Expression and Inhibit Leydig Tumor Growth
}

Salvatore Panza, ${ }^{*}$ Rocco Malivindi, ${ }^{*}$ Francesca Chemi, ${ }^{*}$ Vittoria Rago, ${ }^{*}$ Cinzia Giordano, ${ }^{\dagger}$ Ines Barone, ${ }^{*}$ Daniela Bonofiglio, Luca Gelsomino, ${ }^{*}$ Francesca Giordano, ${ }^{*}$ Sebastiano Andò, ${ }^{\dagger}{ }^{\dagger}$ and Stefania Catalano*

From the Department of Pharmacy, Health and Nutritional Sciences, ${ }^{*}$ and the Health Center, ${ }^{\dagger}$ University of Calabria, Arcavacata di Rende, Cosenza, Italy

\author{
Accepted for publication \\ December 28, 2015 \\ Address correspondence to \\ Sebastiano Andò, M.D., or \\ Stefania Catalano, M.D., \\ Department of Pharmacy, \\ Health and Nutritional Sci- \\ ences, University of Calabria, \\ 87036 Arcavacata di Rende \\ (CS), Italy. E-mail: sebastiano. \\ ando@unical.it or stefania. \\ catalano@unical.it.
}

\begin{abstract}
Leydig cell tumors are the most frequent interstitial neoplasms of the testis with increased incidence in recent years. They are hormonally active and are considered one of the steroid-secreting tumors. Although usually benign, the malignant phenotype responds poorly to conventional chemotherapy or radiation, highlighting the need to identify new therapeutic targets for treatment. Here, we identified a novel glucocorticoid-mediated mechanism that controls cell growth in Leydig cell tumors. We found that a synthetic glucocorticoid receptor agonist, dexamethasone, reduces cell proliferation in rat Leydig tumor cells by decreasing the expression and the enzymatic activity of the estrogen-producing enzyme aromatase. This inhibitory effect relies on the ability of activated glucocorticoid receptor to regulate the aromatase gene transcriptional activity through the recruitment of nuclear receptor corepressor protein and silencing mediator of retinoid and thyroid hormone receptors to a newly identified putative glucocorticoid responsive element within the aromatase promoter II. Our in vivo studies reveal a reduction of tumor growth, after dexamethasone treatment, in animal xenografts. Tumors from dexamethasone-treated mice exhibit a decrease in the expression of the proliferation marker Ki-67 and the aromatase enzyme. Our data demonstrate that activated glucocorticoid receptor, decreasing aromatase expression, induces Leydig tumor regression both in vitro and in vivo, suggesting that glucocorticoid receptor might be a potential target for the therapy of Leydig cell tumors. (Am J Pathol 2016, 186: 1328-1339; http://dx.doi.org/ 10.1016/j.ajpath.2015.12.024)
\end{abstract}

Leydig cell tumors (LCTs) are the most common tumors of the gonadal stroma and represent about $3 \%$ of all testicular neoplasms. ${ }^{1}$ Several observations on both rodents and humans suggest that local estrogen synthesis plays a significant role in sustaining Leydig cell tumorigenesis. Transgenic mice overexpressing aromatase, the enzyme responsible for the conversion of androgens to estrogens, and exhibiting an enhancement of circulating $17 \beta$-estradiol concentrations show Leydig cell hyperplasia and tumors. ${ }^{2,3}$ In a previous study, we observed that the rat Leydig tumor (R2C) cells release a conspicuous amount of $17 \beta$-estradiol, as a consequence of aromatase overexpression that stimulates a short autocrine loop that determines cell proliferation. ${ }^{4}$ In humans, elevated aromatase expression with subsequent high plasma estradiol concentrations has been reported in patients with testicular LCTs, ${ }^{5-8}$ further supporting the crucial role played by the aromatase enzyme on the pathogenesis of leydigiomas. All these experimental and clinical observations suggest that a reduction of local estrogen production by inhibiting aromatase expression may open new opportunities for therapeutic intervention in LCTs.

In this context, we have previously shown that a decrease of aromatase expression induced by farnesoid $\mathrm{X}$ receptor plays an important role in inhibiting Leydig tumor cell growth. ${ }^{9,10}$ Particularly, we have demonstrated that farnesoid

\footnotetext{
Supported by Associazione Italiana Ricerca sul Cancro (AIRC) grant IG 11595; FIRC grant 16487 to L.G.; European Commission, European Social Fund, and the Region of Calabria and Lilli Funaro Foundation to S.P.

S.P. and R.M. contributed equally to this work.

S.A. and S.C. contributed equally to this work as senior authors.

Disclosures: None declared.
} 
$\mathrm{X}$ receptor is able to compete with the steroidogenic factor 1 in binding to a common nuclear response element within the aromatase promoter II (PII), interfering negatively with its activity. ${ }^{9}$ More recently, we also have identified the existence of a functional cross talk between the androgen receptor, the orphan nuclear receptor DAX-1, and aromatase involved in the inhibition of the estrogen-dependent Leydig cancer cell proliferation. $^{11}$

Glucocorticoid receptor (GR), another member of the nuclear receptor superfamily, highly expressed in Leydig cells ${ }^{12-14}$ plays a physiologic role in the control of male sexual maturation and adult reproductive functions that modulate gonadal steroid synthesis and spermatogenesis. ${ }^{15}$ It is well recognized that elevated glucocorticoid concentrations that result from diverse stressful conditions, both physical and psychological, lead to suppression of serum testosterone concentrations. ${ }^{16}$ Conversely, reduction of endogenous corticosterone concentrations (the main glucocorticoid in rodents) leads to increased testosterone production by Leydig cells, thus supporting the repressive role of glucocorticoids on testosterone production. ${ }^{17}$ These observations well fit with the evidences that activation of GR suppresses, in Leydig cells, expression of several steroidogenic enzyme-encoding genes, including Star, Cyp11a1, Cyp17a1, Hsd3b1, Hsd17b3, and Cyp19a1. ${ }^{18-24}$ In addition to the repression of gene expression, glucocorticoids also induce apoptosis in rat Leydig cells. ${ }^{25}$ However, information about the role of GR in Leydig tumor cells is still lacking.

Here, we investigated in the R2C cells whether GR activation by the specific agonist dexamethasone (DEXA) may modulate aromatase expression and thus inhibit testicular tumor growth. We report the identification of a novel glucocorticoid-mediated mechanism that controls the expression of aromatase in Leydig tumor cells by negatively regulating aromatase transcript and protein levels. Transcriptional repression of aromatase gene by GR appears to be consequent to the recruitment of the nuclear receptor corepressor protein $(\mathrm{NCoR})$ and the silencing mediator of retinoid and thyroid hormone receptor (SMRT) corepressors to the glucocorticoid response element (GRE)-containing region of the aromatase promoter.

\section{Materials and Methods}

\section{Reagents and Antibodies}

Nutrient Mixture F-12 Ham, Dulbecco's modified Eagle's medium/Ham's F-12, penicillin, streptomycin, fetal bovine serum (FBS), horse serum, DEXA, mifepristone (RU-486), aprotinin, leupeptin, phenylmethylsulfonyl fluoride, sodium orthovanadate, formaldehyde, NP-40, MTT, dimethyl sulfoxide, and proteinase $\mathrm{K}$ were from Sigma (Milan, Italy). TRIzol was provided by Invitrogen (Carlsbad, CA). FuGENE HD Transfection Reagent, TaqDNA polymerase, RETROscript kit, Dual Luciferase kit by Promega (Madison, WI). SYBR Green Universal PCR Master Mix was from Bio-Rad (Hercules, CA). Antibodies against GR (E-20), p53 (DO-1), p27 ${ }^{\text {Kip1 }}$ (SX53G8.5), p21 ${ }^{\text {WAF1/CIP1 }}(\mathrm{H}-164)$, Cyclin D1 (M-20), $\beta$-Actin (AC-15), glyceraldehyde-3phosphate dehydrogenase (FL-335), RNA polymerase II (N20), ki-67 (M-19), NCoR (H-303), SMRT (N-20), and Luminol Reagent for Enhanced Chemiluminescence system were from Santa Cruz Biotechnology (Santa Cruz, CA); antibody against Aromatase was from Serotec (Raleigh, NC). $[1 \beta-3 \mathrm{H}]$ androst-4-ene-3,17-dione was from PerkinElmer (Wellesley, MA). Salmon sperm DNA/protein A-agarose was from UBI (Chicago, IL).

\section{Cell Cultures}

R2C cells were acquired in 2011 from ATCC (LGC Standards, Tedding-ton Middlesex, UK) where they were authenticated, stored according to supplier's instructions, and used within 4 months after frozen aliquots were resuscitated. R2C cells were cultured in Ham's F-12 supplemented with $15 \%$ horse serum, $2.5 \%$ FBS, and antibiotics. Mouse normal Leydig (TM3) cells were cultured in Dulbecco's modified Eagle's medium/Ham's F-12 supplemented with $5 \%$ horse serum, $2.5 \%$ FBS, and antibiotics.

\section{Immunoblot Analysis}

R2C and TM3 cells were lyzed in $500 \mu \mathrm{L}$ of $50 \mathrm{mmol} / \mathrm{L}$ Tris$\mathrm{HCl}, 150 \mathrm{mmol} / \mathrm{L} \mathrm{NaCl}, 1 \%$ Nonidet P-40, $0.5 \%$ sodium deoxycholate, $2 \mathrm{mmol} / \mathrm{L}$ sodium fluoride, $2 \mathrm{mmol} / \mathrm{L}$ EDTA, $0.1 \%$ SDS, containing a mixture of protease inhibitors (aprotinin, phenylmethylsulfonyl fluoride, and sodium orthovanadate) for protein extraction. Protein extracts from tumor tissues were homogenized in lysis buffer supplemented with $10 \%$ glycerol. Equal amounts PAGE, as described. ${ }^{26}$

\section{Immunofluorescence}

R2C cells were seeded on glass coverslips, washed with phosphate-buffered saline (PBS), and then fixed with $4 \%$ paraformaldehyde in PBS for 20 minutes at room temperature. Next, cells were permeabilized with $0.2 \%$ Triton X-100 in PBS for 5 minutes, blocked with $5 \%$ bovine serum albumin for 30 minutes, and incubated overnight with anti-GR antibody (dilution 1:100) in PBS at $4{ }^{\circ} \mathrm{C}$. The day after the cells were washed three times with PBS and incubated with the secondary antibody anti-rabbit IgG-fluorescein isothiocyanate (dilution 1:200) for 1 hour at room temperature. To check the specificity of immunolabeling the primary antibody was replaced by normal rabbit serum (negative control). Fluorescence was photographed with Olympus BX51 microscope (Tokyo, Japan) with a $40 \times$ objective.

\section{Total RNA Extraction and RT-PCR Assay}

Total RNA was extracted from R2C cells with the use of TRIzol reagent, and evaluation of gene expression was 
performed by the RT-PCR method with the use of a RETROscript kit. The cDNAs obtained were amplified by PCR with the use of the following primers: forward $5^{\prime}$-CAGCTATACTGAAGGAATCCACACTGT- $3^{\prime}$ and reverse $5^{\prime}$ AATCGTTTCAAAAGTGTAACCAGGA-3' (P450 aromatase); forward 5'-GAAATCGCCAATGCCAACTC- $3^{\prime}$ and reverse $5^{\prime}$-ACCTTCAGGTACAGGCTGTG-3' (L19). The PCR was performed for 25 cycles for P450 aromatase $\left(94^{\circ} \mathrm{C}\right.$ for 1 minute, $58^{\circ} \mathrm{C}$ for 1 minute, and $72^{\circ} \mathrm{C}$ for 2 minutes), and 20 cycles for $\mathrm{L} 19\left(94^{\circ} \mathrm{C}\right.$ for 1 minute, $60^{\circ} \mathrm{C}$ for 1 minute, and $72^{\circ} \mathrm{C}$ for 2 minutes) in the presence of $1 \mu \mathrm{L}$ of first-strand cDNA, $1 \mu \mathrm{mol} / \mathrm{L}$ each of the primers, $0.5 \mathrm{mmol} / \mathrm{L}$ dNTP, Taq DNA polymerase (2 U/tube), and $2.2 \mathrm{mmol} / \mathrm{L}$ magnesium chloride in a final volume of $25 \mu \mathrm{L}$. DNA quantity in each lane was analyzed by ImageJ version 1.45 (NIH, Bethesda, MD; http://imagej.nih.gov/ij).

\section{Aromatase Activity Assay}

The aromatase activity in subconfluent $\mathrm{R} 2 \mathrm{C}$ cell culture medium was measured by the tritiated water release assay with the use of $0.5 \mu \mathrm{mol} / \mathrm{L}[1 \beta-3 \mathrm{H}]$ androst-4-ene-3,17-dione as substrate. ${ }^{10}$ The incubations were performed at $37^{\circ} \mathrm{C}$ for 2 hours under an air/ $\mathrm{CO}_{2}(5 \%)$ atmosphere. The results obtained were expressed as picomole/h and were normalized to $\mathrm{mg}$ of protein ( $\mathrm{pmol} / \mathrm{h}$ per $\mathrm{mg}$ of protein).

\section{Plasmids, Transfections, and Luciferase Reporter Assays}

R2C cells were transiently transfected with FuGENE HD reagent with the plasmids that contained different segments of the rat aromatase PII sequence ligated to a luciferase reporter gene $-1037 /+94(\mathrm{p}-1037),-688 /+94(\mathrm{p}-688),-475 /+94$ (p-475), $-183 /+94$ (p-183) previously described. ${ }^{27}$ After transfection, R2C cells were treated with DEXA $(0.01,0.1,1$ $\mu \mathrm{mol} / \mathrm{L})$ for 24 hours. Thymidine kinase Renilla luciferase plasmid was used to normalize the efficiency of the transfection. Firefly and Renilla luciferase activities were measured by the Dual Luciferase kit. The firefly luciferase data for each sample were normalized on the basis of transfection efficiency measured by Renilla luciferase activity.

\section{ChIP and Re-ChIP Assay}

R2C cells were treated with 0.1 and $1 \mu \mathrm{mol} / \mathrm{L}$ DEXA for 1 hour and then cross-linked with $1 \%$ formaldehyde and sonicated. Supernatant fluids were immunocleared with salmon sperm DNA/protein A-agarose for 1 hour at $4^{\circ} \mathrm{C}$. For chromatin immunoprecipitation (ChIP), the precleared chromatin was immunoprecipitated with specific anti-GR or anti-polymerase II antibodies and re-immunoprecipitated with anti-NCoR or anti-SMRT antibodies. A normal mouse serum IgG was used as negative control. Pellets were washed as reported, eluted with elution buffer (1\% SDS, 0.1 $\mathrm{mol} / \mathrm{L} \mathrm{NaHCO}_{3}$ ), and digested with proteinase K. DNA was obtained by phenol/chloroform/isoamyl alcohol extractions and precipitated with ethanol. A 5- $\mu \mathrm{L}$ volume of each sample and input were used for real-time PCR with the use of the primers flanking the GRE sequence in the P450 aromatase PII region: 5'-GTAGAAGGGTACAGTTCTCGG- $3^{\prime}$ and $5^{\prime}$-CCTAGGACACACATGCTCAC- $3^{\prime}$. PCR were performed in the iCycler iQ Detection System (Bio$\mathrm{Rad}$ ), with the use of $0.1 \mu \mathrm{mol} / \mathrm{L}$ of each primer, in a total volume of $30 \mu \mathrm{L}$ of reaction mixture according to the manufacturer's recommendations. SYBR Green Universal PCR Master Mix with the dissociation protocol was used for gene amplification. Negative controls contained water instead of DNA. Final results were calculated with the $\Delta \Delta \mathrm{Ct}$ method as previously reported, ${ }^{4}$ using input $\mathrm{Ct}$ values. The basal sample was used as calibrator.

\section{Cell Viability and Proliferation Assays}

\section{MTT Assay}

Cell viability was determined by using the MTT assay as previously described. ${ }^{28}$ Results are expressed as fold change \pm SD relative to vehicle-treated cells and are representative of three different experiments, each performed in triplicate.

\section{Soft Agar Anchorage-Independent Growth Assays}

Cells $\left(10^{4} /\right.$ well) were plated in $2 \mathrm{~mL}$ of $0.5 \%$ agarose with $5 \%$ charcoal stripped-FBS in phenol red-free media, with a $0.7 \%$ agarose base in 6-well plates. Two days after plating, media that contained vehicle or treatments as indicated were added to the top layer and replaced every 2 days. After 14 days, colonies were counted as described. ${ }^{29}$ Data shown are the mean colony numbers of three plates and are representative of three independent experiments, each performed in triplicate.

\section{DNA Flow Cytometry}

To determine cell cycle distribution analysis, cells were harvested by trypsinization, fixed, and stained with $100 \mu \mathrm{g} / \mathrm{mL}$ propidium iodide after treatment with $20 \mu \mathrm{g} / \mathrm{mL}$ RNase A. The DNA content was measured with a FACScan flow cytometer (Becton Dickinson, Mountain View, CA) and the data acquired with CellQuest software version 3.3. Cell cycle profiles were determined with ModFit LT.

\section{In Vivo Experiments}

The in vivo experiments were performed in 35-day-old male nude mice (nu/nu Swiss; Charles River, Milan, Italy). At day 0 , mice were inoculated with $1.0 \times 10^{5} \mathrm{R} 2 \mathrm{C}$ cells/ mouse into the intrascapular region. DEXA treatment was started at day 14 later and delivered daily to the animals by i.p. injection. Tumor growth was monitored as described. ${ }^{30}$ At the time of sacrificing, 30 days after injection, tumors were dissected from the neighboring connective tissue, 
frozen in nitrogen, and stored at $-80^{\circ} \mathrm{C}$. All animals were maintained and handled in accordance with the recommendation of the Guidelines for the Care and Use of Laboratory Animals and were approved by the Animal Care Committee of University of Calabria.

\section{Histopathologic Analysis}

Tumor, testis, livers, spleen, and kidneys were fixed in $4 \%$ formalin, sectioned at $5 \mu \mathrm{m}$, and stained with hematoxylin and eosin, as suggested by the manufacturer (Bio-Optica, Milan, Italy). Hematoxylin and eosin was photographed with Olympus BX51 microscope with a $20 \times$ objective.

\section{Immunohistochemical Analysis}

Paraffin-embedded section, $5 \mu \mathrm{m}$ thick, were mounted on slides precoated with polylysine, and then they were deparaffinized and dehydrated (seven to eight serial sections). Immunohistochemical experiments were performed as described, ${ }^{31}$ using rabbit polyclonal Ki-67 and mouse monoclonal anti-aromatase primary antibody at $4{ }^{\circ} \mathrm{C}$ overnight. For the detection of GR in human LCT, formalinfixed, paraffin-embedded testicular tissue, obtained from one male patient (aged 33 years) provided by the Pathological Anatomy Unit (Annunziata Hospital, Cosenza, Italy), was incubated with rabbit polyclonal GR. Then, a biotinylated goat-anti-rabbit and goat-anti-mouse IgG was applied for 1 hour at room temperature, followed by the avidin biotin-horseradish peroxidase complex (Vector Laboratories, Burlingame, CA). Immunoreactivity was visualized by using the diaminobenzidine chromogen (SigmaAldrich, St. Louis, MO) method. The primary antibody was replaced by normal rabbit and normal mouse serum negative control section. Immunohistochemical experiments were photographed with Olympus BX51 microscope with a $40 \times$ objective.

\section{Statistical Analysis}

Each datum point represents the means \pm SD of three different experiments. Data were analyzed by Student's $t$-test with the use of the GraphPad Prism 4 software program (GraphPad Inc., San Diego, CA). $P<0.05$ was considered statistically significant.

\section{Results}

\section{GR Is Expressed in R2C Cells}

We first evaluated, by immunoblot analysis, the expression of GR in the R2C cell line, a well-documented experimental model for leydigioma. ${ }^{4,-11,27}$ Indeed, it has been shown that these cells, similar to human LCTs, exhibit high aromatase expression and activity, leading to a consequent excess of in situ estradiol production that sustains tumor cell survival and proliferation. ${ }^{4-8,27}$ We showed the presence of a GR-immunoreactive protein band whose levels were comparable with those observed in TM3 cells, an immortalized Leydig cell line derived from normal mouse testis (Supplemental Figure S1A). These results were further confirmed by immunofluorescence analysis that detected GR immunoreactivity in the cytoplasm region of R2C cells. No fluorescence was noticed in the cells processed without primary antibody (NC) (Supplemental Figure S1B). Moreover, a positive GR immunostaining was revealed in neoplastic cells from human Leydig tumors (Supplemental Figure S1C), indicating that human LCTs do express GR.

\section{Inhibitory Effects of the GR Agonist DEXA on Aromatase Expression in R2C Cells}

On the basis of previous data to indicate that GR activation down-regulates the aromatase enzyme in testes, ${ }^{24}$ we explored the possibility that the GR agonist DEXA might modulate aromatase gene expression in R2C cells. Treatment with $0.01,0.1$, and $1 \mu \mathrm{mol} / \mathrm{L}$ DEXA was able to reduce the cellular content of the enzyme, in a concentration-dependent manner, at both mRNA and protein levels, as determined by RT-PCR and immunoblot analyses (Figure 1, A and B). The reduction of aromatase expression on DEXA administration was also reflected by a change in its enzymatic activity, as evaluated by the tritiated water release assay (Figure 1C). A direct involvement of GR in modulating aromatase expression was provided by the evaluation of aromatase mRNA levels, protein content, and enzymatic activity after administration of the GR inhibitor RU-486 in R2C cells treated with DEXA (Figure 1, D-F). The addition of RU-486 completely reversed the down-regulatory effects induced by DEXA, suggesting that activated GR may directly regulate aromatase expression in R2C cells.

\section{Ligand-Activated GR Decreases the Transcriptional Activity of Aromatase Proximal PII}

Next, we tested whether the down-regulatory effects of DEXA on aromatase expression could be due to a negative influence on aromatase gene transcriptional activity. Aromatase activity is regulated primarily at the level of gene expression by tissuespecific promoters and is present in testicular somatic cells and along the maturative phases of male germ cells. ${ }^{32,33}$ Specifically, a promoter proximal to the translation start site, PII, regulates aromatase expression in fetal and adult testis, R2C and $\mathrm{H} 540$ rat Leydig tumor cells, and in purified preparations of rat Leydig, Sertoli, and germ cells. ${ }^{34,35}$

Thus, R2C cells were transiently transfected with a luciferase reporter construct containing the PII-aromatase promoter sequence $(-1037 /+94, \mathrm{p}-1037)$ and treated with increasing concentrations of DEXA. We found a significant dose-dependent inhibition of aromatase promoter activity after treatment with DEXA (Figure 2A). To identify the region within the aromatase promoter that is functionally 
A

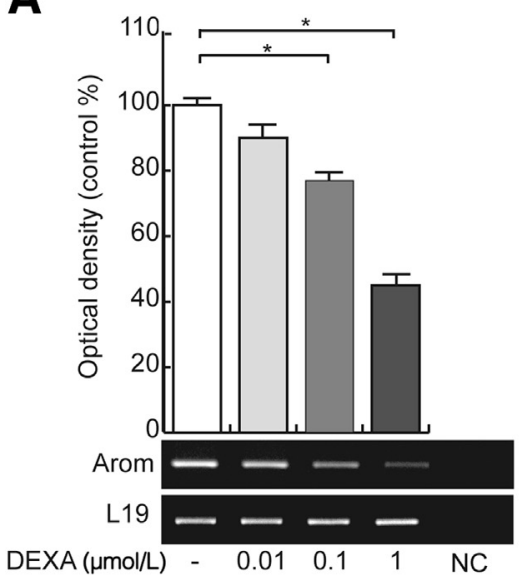

D

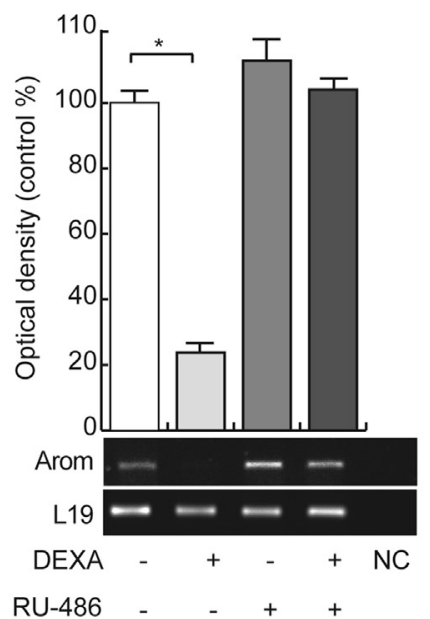

B

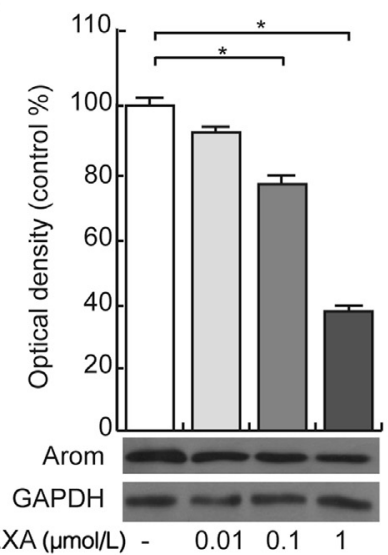

$\mathbf{E}$

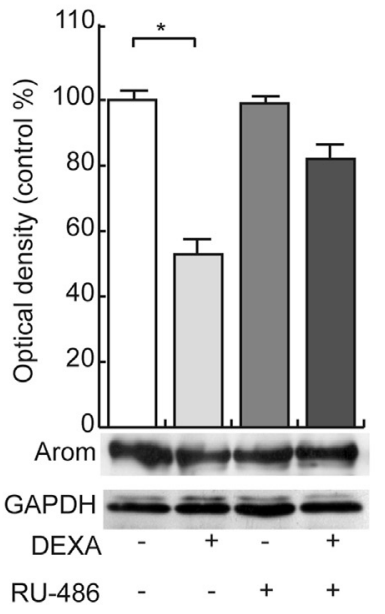

C

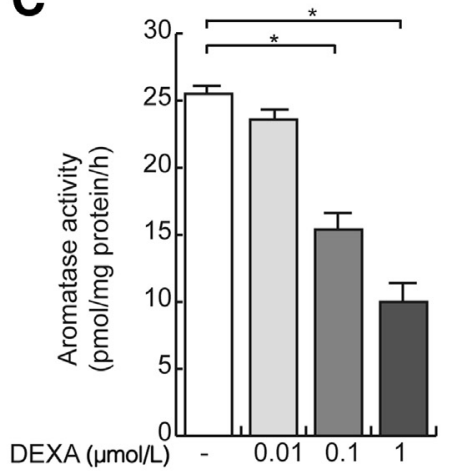

$\mathbf{F}$

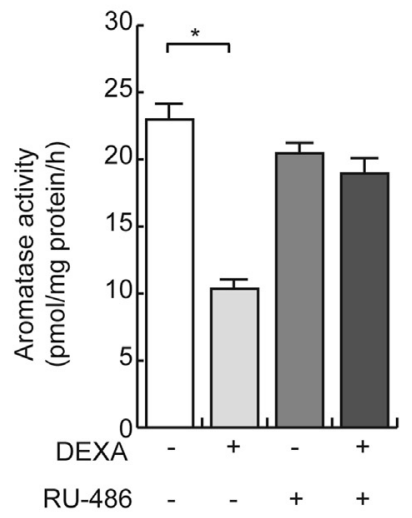

Figure 1 Effects of DEXA on aromatase expression and activity in R2C cells. A: Total RNA was extracted from R2C cells treated with vehicle (-) or 0.01, 0.1, and $1 \mu \mathrm{mol} / \mathrm{L}$ DEXA for 24 hours and reverse transcribed. CDNA was subjected to PCR with the use of primers specific for Arom or L19. L19 was used as a loading control. B: Total proteins extracted from R2C cells treated with vehicle (-) or $0.01,0.1$, and $1 \mu$ mol/L DEXA for 24 hours were used for immunoblot analysis of Arom. GAPDH was used as a loading control. C: R2C were cultured in the presence of vehicle (-) or $0.01,0.1$, and $1 \mu \mathrm{mol} / \mathrm{L}$ DEXA for 24 hours. Arom activity was performed as described in Material and Methods. The results obtained were expressed as picomole of [ $\left.{ }^{3} \mathrm{H}\right] \mathrm{H}_{2} \mathrm{O} / \mathrm{h}$ of release and were normalized for milligrams of protein (pmol/mg of proteins per hour). D-F: R2C cells were treated with DEXA $1 \mu \mathrm{mol} / \mathrm{L}$ with or without RU-486 $5 \mu \mathrm{mol} / \mathrm{L}$ for 24 hours, and RT-PCR (D), immunoblot analysis (E), and Arom activity (F) were performed. Data are expressed as means \pm SD. $n=3$ different experiments each performed with triplicate samples $(\mathbf{C}$ and $\mathbf{F}) ; n=3$ separate experiments in which band intensities were evaluated in terms of optical density arbitrary units and expressed as percentages of the control, which was assumed to be $100 \%$ (A, B, D, and E). ${ }^{\star} P<0.05$. Arom, aromatase; DEXA, dexamethasone; GAPDH, glyceraldehyde 3phosphate dehydrogenase; NC, negative control, RNA sample without the addition of reverse transcriptase; R2C, rat Leydig tumor.

important for transcriptional regulation by DEXA, transient transfection experiments were performed by using constructs that contained different $5^{\prime}$-deleted regions of the rat PII-aromatase promoter (Figure 2B). Similarly to what was observed for the PII-aromatase promoter $(-1037 /+94)$, the transcriptional activity of the PII-aromatase promoter constructs $(-688 /+94, \mathrm{p}-688$ and $-475 /+94, \mathrm{p}-475)$ was decreased in response to DEXA stimulation; whereas, in the presence of the PII-aromatase promoter construct encoding the sequence from -183 to +94 ( $\mathrm{p}$-183), we evidenced the loss of the DEXA-mediated inhibitory effect (Figure 2B). This latter result highlights that the region from -475 to -183 was essential for the down-regulation induced by DEXA on aromatase promoter activity. The nucleotide sequence analysis of this region revealed a putative GRE binding motif located at position $-470 /-460$, suggesting that $\mathrm{P} 450$ aromatase regulation by DEXA may require GRE motif.

\section{GR Reduces Aromatase Promoter Activity at GRE Site} through Specific Corepressor Recruitment

The role of GR in regulating the aromatase gene promoter activity was further investigated by ChIP assay. With the use of specific antibody against GR and RNA-Pol II, protein-chromatin complexes were immunoprecipitated from R2C cells cultured with or without DEXA at 0.1- and $1-\mu \mathrm{mol} / \mathrm{L}$ doses. GR occupancy to the GRE site-containing 
A
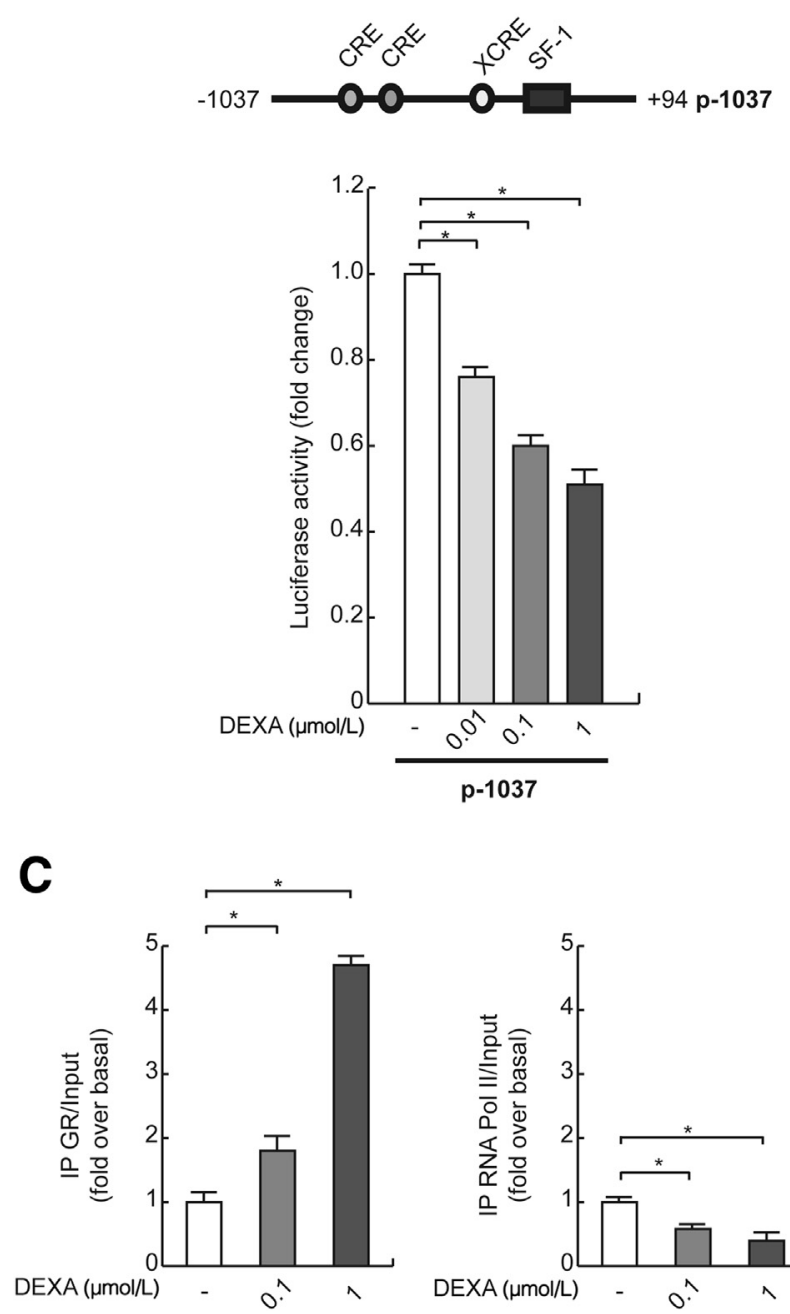

B
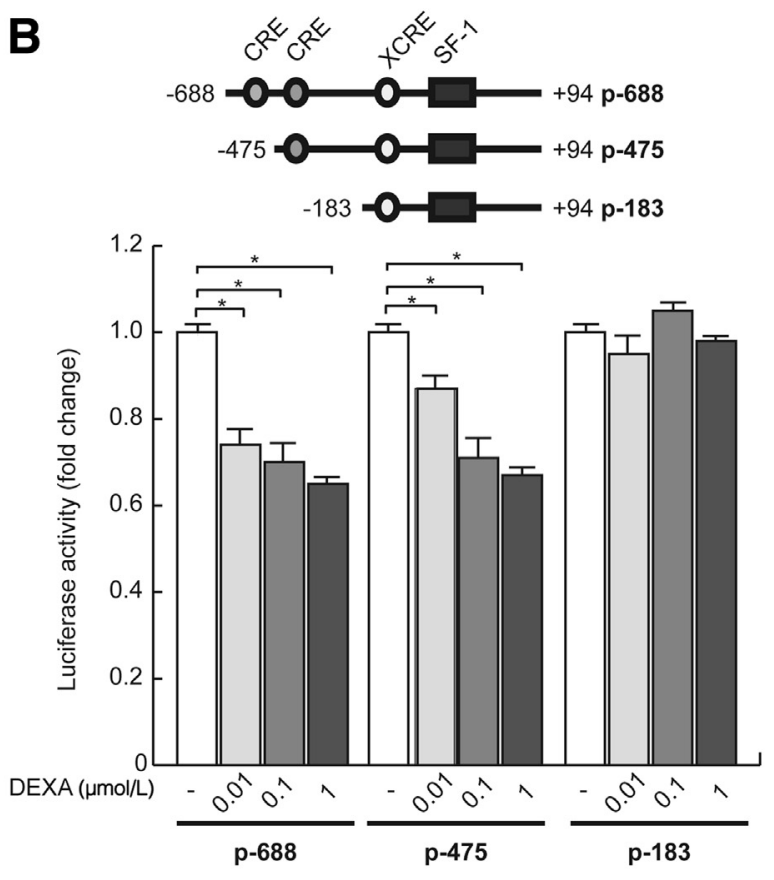

D

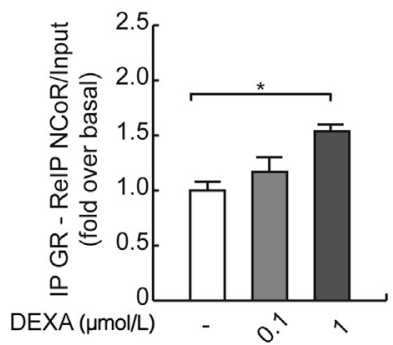

Figure 2 DEXA decreases transcriptional activity of aromatase proximal PII. A and B: Schematic map of the P450 aromatase proximal PII constructs. All of the promoter constructs contain the same $3^{\prime}$ boundary $(+94)$. The $5^{\prime}$ boundaries of the promoter fragments varied from -1037 to $-183(\mathrm{p}-1037, \mathrm{p}-688, \mathrm{p}-475, \mathrm{p}-183)$. R2C cells were transiently transfected with the reported constructs and treated for 24 hours with vehicle $(-)$ or $0.01,0.1$, and $1 \mu \mathrm{mol} / \mathrm{L}$ DEXA. C: R2C cells were treated in the presence of vehicle (-) or 0.1 and $1 \mu \mathrm{mol} / \mathrm{L} \mathrm{DEXA}$ for 1 hour, then cross-linked with formaldehyde, and lyzed. The precleared chromatin was immunoprecipitated with antiGR, and anti-RNA Pol II antibodies. D: Chromatin immunoprecipitated with the anti-GR antibody was re-immunoprecipitated with anti-NCoR and SMRT antibodies. The PII sequence, including the GRE site, was detected by real-time PCR with specific primers, as described in Material and Methods. Data are expressed as means \pm SD. $n=3$ different experiments performed in triplicate. ${ }^{*} P<0.05$. DEXA, dexamethasone; GR, glucocorticoid receptor; GRE, glucocorticoid response element; IP, immunoprecipitated; PII, promoter II; NCoR, nuclear receptor corepressor protein; R2C, rat Leydig tumor; SMRT, silencing mediator of retinoid and thyroid hormone receptors.

sequence of aromatase promoter was induced in a liganddependent manner by DEXA (Figure 2C). The negative transcriptional role of GR on aromatase expression is evidenced by the dynamic of RNA Pol II recruitment onto the aromatase promoter that appears to be drastically reduced on DEXA treatment (Figure 2C). To assess whether the decrease in aromatase promoter transcriptional activity might be caused by the cooperative interaction between GR and negative transcriptional regulators, we investigated the involvement of NCoR and SMRT, which interact with GR and function as negative coregulators. ${ }^{36}$ Re-ChIP assays demonstrated increased NCoR and SMRT occupancy of the GRE-containing aromatase promoter region after DEXA exposure (Figure 2D).

\section{DEXA Inhibits R2C Cell Proliferation through GR Activation}

We have previously demonstrated that local estradiol production by highly expressed aromatase represents a major feature involved in the positive control of R2C cell proliferation. ${ }^{4}$ Thus, the effect of increasing concentrations of DEXA on R2C cell viability was evaluated by MTT assay. Treatment with DEXA at $0.01,0.1$, and $1 \mu \mathrm{mol} / \mathrm{L}$ doses for 24 and 48 hours significantly decreased $\mathrm{R} 2 \mathrm{C}$ cell viability in a dosedependent manner (Figure 3A). The inhibitory effects exerted by DEXA were completely reversed in the presence of the GR inhibitor RU-486 (Figure 3B). In addition, we examined the effects of activated GR on cell growth with the use 
A

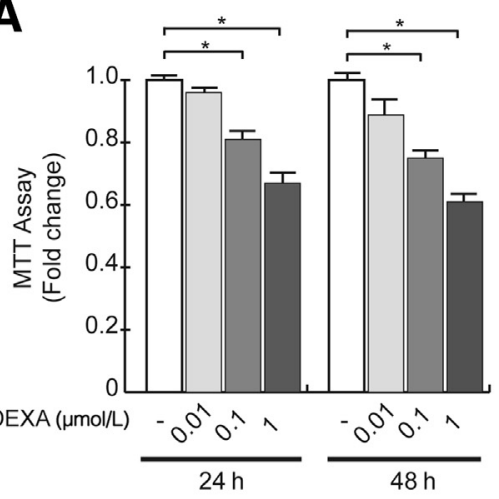

D

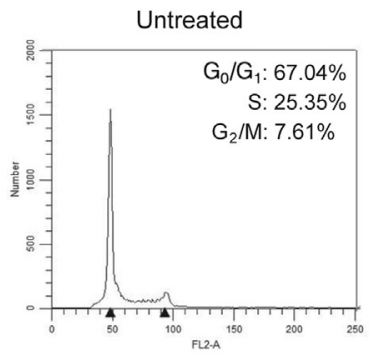

B

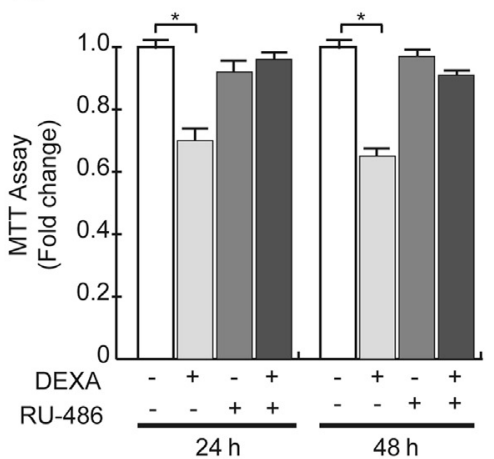

C

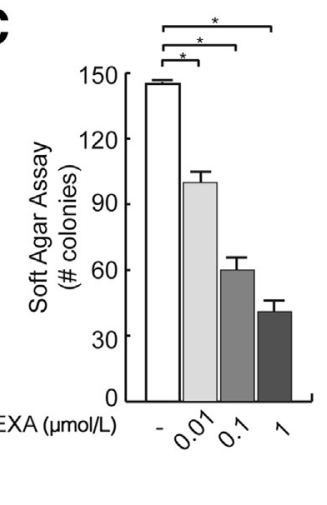

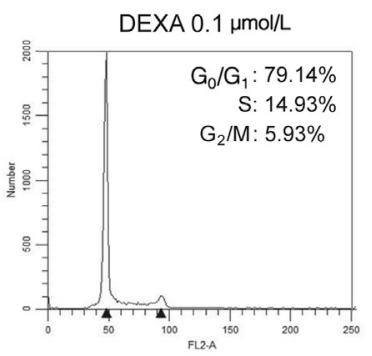

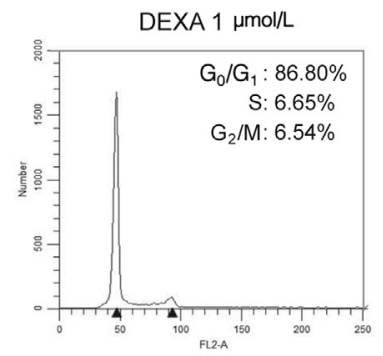

$\mathbf{E}$
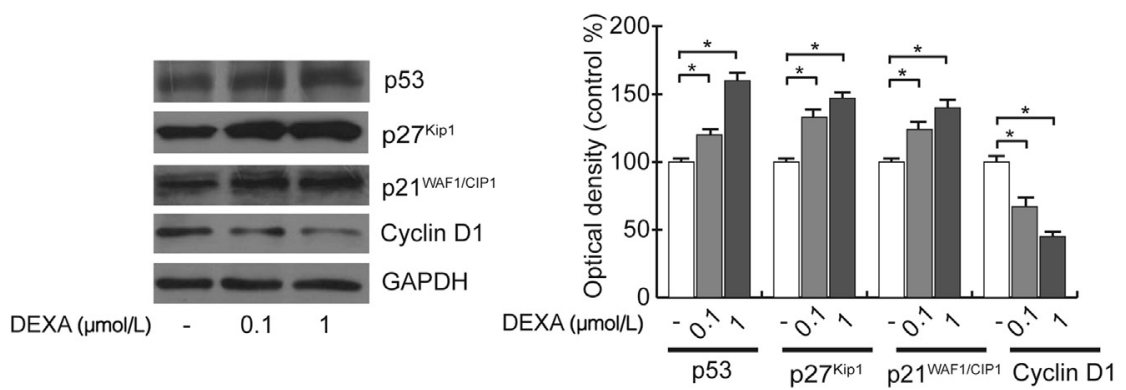

Figure 3 DEXA effects on R2C cell proliferation. A and B: R2C cells were treated with vehicle (-) or $0.01,0.1$, and $1 \mu$ mol/L DEXA (A) or treated with DEXA $1 \mu \mathrm{mol} / \mathrm{L}$ in the presence or absence of RU-486 $5 \mu \mathrm{mol} / \mathrm{L}$ (B) for 24 and 48 hours, before testing cell viability with the MTT assay. C: R2C cells were seeded $(10,000 /$ well $)$ in $0.5 \%$ agarose and treated as described above. Cells were allowed to grow for 14 days, and then the number of colonies $>50 \mu \mathrm{m}$ were quantified, and the results were graphed. D: R2C cells untreated or treated with 0.1 and $1 \mu \mathrm{mol} / \mathrm{L}$ DEXA for 24 hours were stained with propidium iodide, and cell cycle distribution was analyzed by fluorescence-activated cell sorting. E: Total proteins extracted from R2C cells treated with vehicle (-) or 0.1 and 1 $\mu \mathrm{mol} / \mathrm{L}$ DEXA for 24 hours were used for immunoblot analysis of p53, p2 $7^{\mathrm{Kip} 1}, \mathrm{p} 21^{\text {WAF1/CIP1 }}$, and Cyclin D1. GAPDH was used as a loading control. Data are expressed as fold-change \pm SD relative to vehicle-treated cells $(\mathbf{A}$ and $\mathbf{B})$, the percentage of live cell population in each phase of the cell cycle (D), or means $\pm \mathrm{SD}(\mathbf{E}) . n=3$ different experiments each performed in triplicate $(\mathbf{B}) ; n=2$ independent experiments, each performed in triplicate (D); $n=3$ separate experiments in which band intensities were evaluated in terms of optical density arbitrary units and expressed as percentages of the control, which was assumed to be $100 \%$ (E). ${ }^{*} P<0.05$. DEXA, dexamethasone; GAPDH, glyceraldehyde 3-phosphate dehydrogenase; R2C, rat Leydig tumor.

of anchorage-independent soft agar assays, which better reflect in vivo three-dimensional tumor growth (Figure 3C). Consistent with data from MTT assays, DEXA treatment significantly reduced colony formation in R2C cells. To extend our results, we also investigated the effects of DEXA in affecting growth of TM3 cell line. DEXA exposure did not elicit any significant inhibitory effects in TM3 cells at all of the doses tested (Supplemental Figure S2). This may be due to the different expressions of aromatase between normal and tumor cell lines, because, as previously reported, ${ }^{4}$ TM3 cells show undetectable levels of aromatase protein.

Moreover, to investigate the effects of DEXA on cell cycle progression, flow cytometric analysis was performed in R2C cells. DEXA treatment caused a cell cycle arrest in $\mathrm{G}_{0} / \mathrm{G}_{1}$ phase concomitant with a reduced fraction of cells in S-phase compared with untreated cells (Figure 3D). Accordingly, the expression of cell cycle regulator genes was modulated by DEXA administration as revealed by p53, p27 $7^{\mathrm{Kip} 1}, \mathrm{p} 21^{\mathrm{WAF} 1 / \mathrm{CIP} 1}$ up-regulation and Cyclin D1 down-regulation (Figure 3E).

\section{Activation of GR Inhibits R2C Tumor Xenograft Growth}

As a final step of the current study, we used the R2C tumor xenograft model to examine the effects of DEXA on Leydig tumor growth in vivo. To this aim, we injected R2C cells 


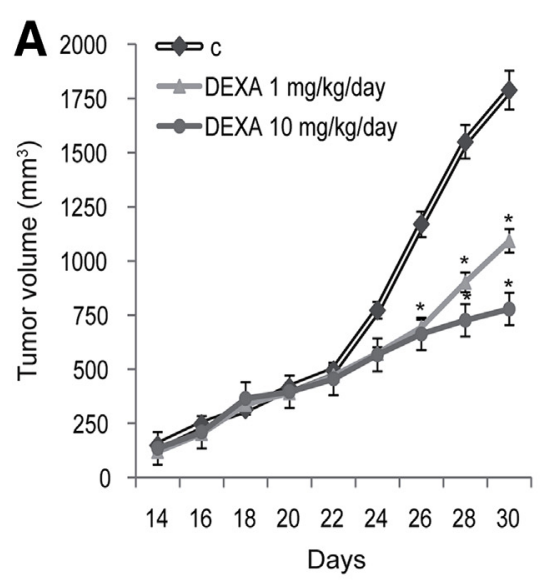

B

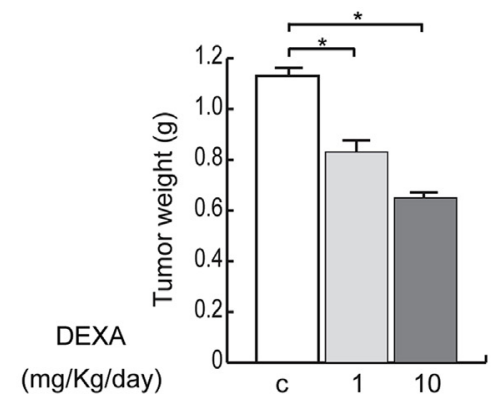

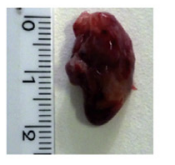

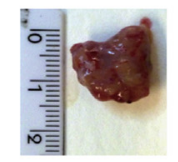

C

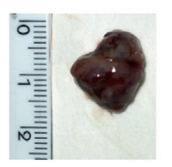

$1 \mathrm{mg} / \mathrm{Kg} /$ day $10 \mathrm{mg} / \mathrm{Kg} /$ day

DEXA
C

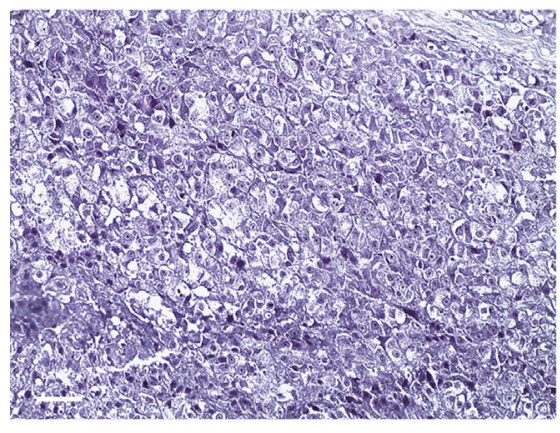

c

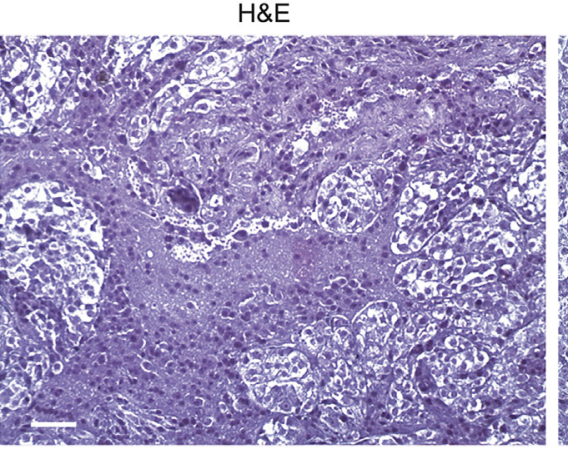

$1 \mathrm{mg} / \mathrm{kg} / \mathrm{day}$

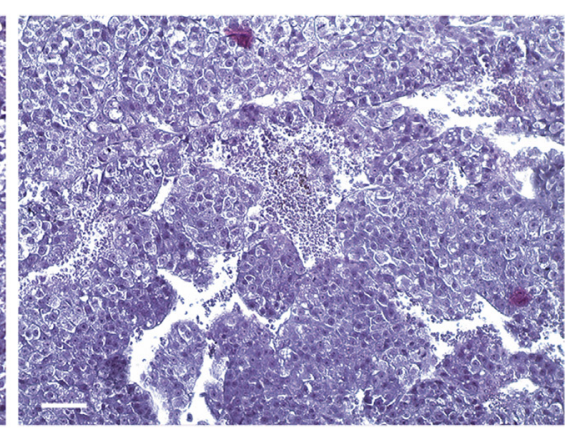

$10 \mathrm{mg} / \mathrm{kg} / \mathrm{day}$

DEXA

Figure 4 DEXA treatment inhibits Leydig tumor growth in vivo. A: R2C cells were injected in male nude mice. After 14 days, mice were assigned randomly to receive $1 \mathrm{mg} / \mathrm{kg} /$ day DEXA, $10 \mathrm{mg} / \mathrm{kg} /$ day DEXA, or vehicle (c), and tumor growth was monitored over time. B: Average tumor weight from vehicle (c) and DEXA-treated mice and the images of a representative individual tumor from each treatment group. C: H\&E-stained histologic images of R2C xenograft tumors. $n=5$ per each condition. ${ }^{*} P<0.05$, DEXA-treated groups versus control group. Scale bar $=25 \mu \mathrm{m} . \mathrm{C}$, control; DEXA, dexamethasone; H\&E, hematoxylin and eosin; R2C, rat Leydig tumor.

into the intrascapular region of male nude mice and followed tumor growth after administration of DEXA at 1 and $10 \mathrm{mg} / \mathrm{kg}$ per day. This administration was well tolerated because no changes in body weight or in food and water consumption were observed along with no evidence of reduced motor function. In addition, no significant differences in the mean weights or histologic features of the major organs (liver, spleen, and kidney) after sacrifice were observed between vehicle- and DEXA-treated mice, indicating a lack of toxic effects at the dose given. Treatment with DEXA at both 1 and $10 \mathrm{mg} / \mathrm{kg}$ per day induced a significant regression in tumor growth (Figure 4A). Thirty days after injection, tumor weight and tumor size were markedly smaller in animals treated with DEXA than in vehicle-treated mice (Figure 4B). Hematoxylin and eosin staining of tumor tissues are shown in Figure 4C. In agreement with our in vitro findings, we observed in $\mathrm{R} 2 \mathrm{C}$ xenograft tumors from mice treated with DEXA a significant decrease of aromatase expression, evaluated by both immunoblotting and immunohistochemistry analysis (Figure 5, A and B). This was concomitant with a reduced expression of Ki-67, a well-known marker for cell proliferation, in $\mathrm{R} 2 \mathrm{C}$ xenograft tumors from mice treated with
DEXA compared with tumors from vehicle-treated mice (Figure 5C).

It is worthwhile to underline that the histopathologic features of seminiferous tubules from DEXA-treated mice showed a normal cellularity and morphology that were similar to those of the control groups (Supplemental Figure S3).

\section{Discussion}

Leydigioma is a rare testicular tumor that affects males at any age with two peaks of incidence, during prepuberty between 5 and 10 years, and in adulthood between 25 and 35 years of age. ${ }^{37}$ Although usually benign, about $10 \%$ of LCTs in adult patients reveal a malignant phenotype that metastasizes to retroperitoneal lymph nodes, liver, lungs, and bone. ${ }^{38}$ Unfortunately, malignant LCTs respond poorly to chemotherapy or radiation, ${ }^{39,40}$ rendering it necessary to identify new therapeutic targets for LCT treatment.

In this study, we have shown that GR is a potential new target to inhibit Leydig tumor cell proliferation. Indeed, GR is expressed in this type of cancer, and its activation is associated with a drastic reduction of cell proliferation that 
A

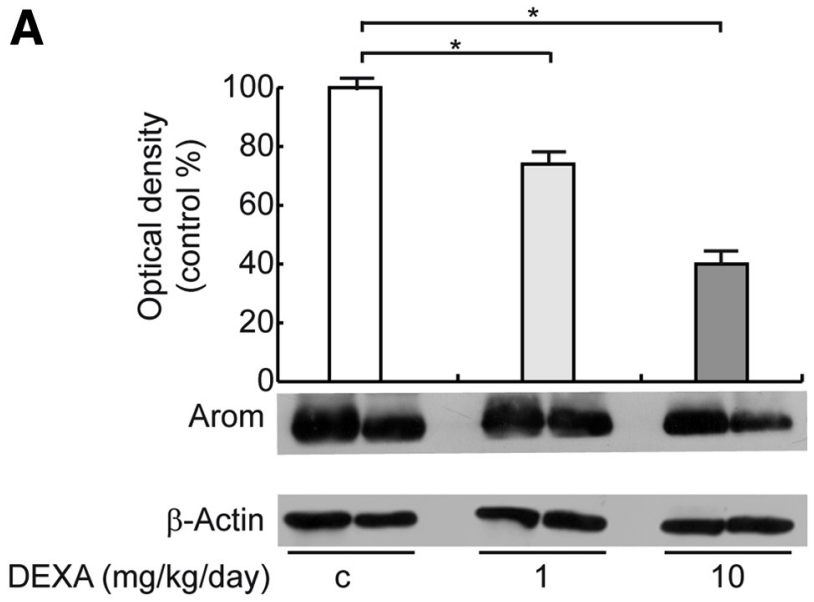

Figure 5 DEXA treatment decreases aromatase expression in R2C tumor xenografts. A: Protein extracts from xenografts excised from vehicle (c) and DEXA-treated mice were tested for aromatase expression by immunoblot analysis. $\beta$-Actin was used as a loading control. B and C: Representative images of aromatase (B) or Ki-67 (C) immunohistochemical staining of $\mathrm{R} 2 \mathrm{C}$ xenograft tumors. Insets indicate negative control. Data are expressed as means \pm SD. $n=3$ separate experiments in which band intensities were evaluated in terms of optical density arbitrary units and expressed as percentages of the control, which was assumed to be $100 \%$. ${ }^{*} P<0.05$. Scale bar $=12.5 \mu \mathrm{m}$. C, control; DEXA, dexamethasone; R2C, rat Leydig tumor.

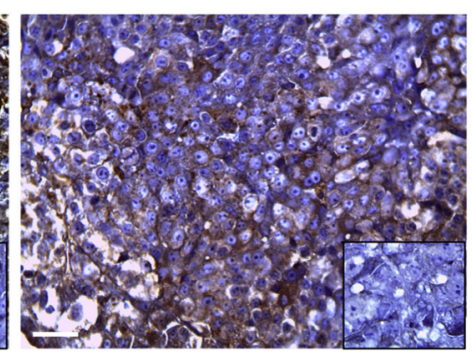

$1 \mathrm{mg} / \mathrm{kg} / \mathrm{day}$

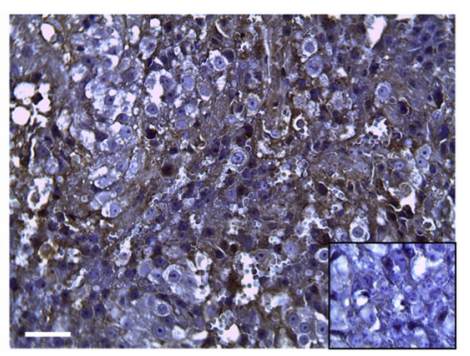

$10 \mathrm{mg} / \mathrm{kg} / \mathrm{day}$

DEXA

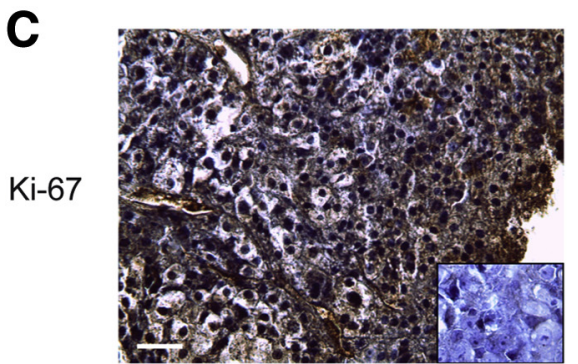

C

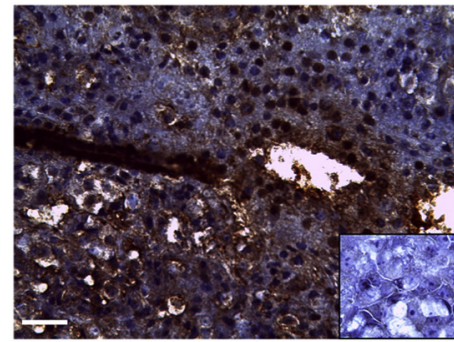

$1 \mathrm{mg} / \mathrm{kg} / \mathrm{day}$

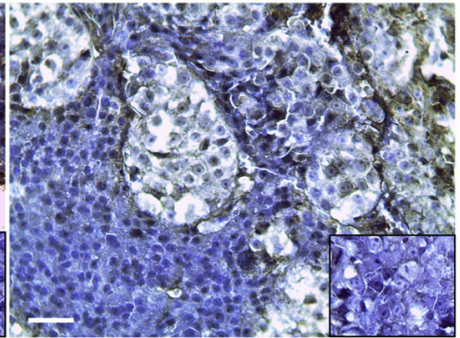

$10 \mathrm{mg} / \mathrm{kg} /$ day

DEXA

results from the inhibition of aromatase expression and activity.

Glucocorticoid hormones control a wide variety of biological processes, such as metabolic homeostasis, inflammation, immune response, development, and reproduction. ${ }^{41}$ Moreover, glucocorticoids are key regulators of cell growth and proliferation in many cell types. They can induce $\mathrm{G}_{0} / \mathrm{G}_{1}$ cell cycle arrest and programed cell death of immature thymocytes, several leukemic cell lines, and mature peripheral $\mathrm{T}$ lymphocytes. ${ }^{42,43}$ They can also inhibit the proliferation of mammary epithelial cells, ${ }^{44,45}$ fibroblasts, ${ }^{46}$ and hepatoma cells. ${ }^{47}$ There are several proposed mechanisms to explain the inhibitory effects of glucocorticoids on cell growth that appear to operate in a cell-type-specific manner. These mechanisms include activation of cyclin-dependent protein kinase inhibitors, transcriptional repression of mitogenic factors, and activation of glycogen synthase kinase-3 $\beta$, resulting in the proteolytic degradation of c-Myc and Cyclin D1. ${ }^{48-50}$ The antiproliferative effect exerted by glucocorticoids has prompted their use clinically as a part of anticancer therapy for a diverse range of dysplasias, including lymphoproliferative disorders and several solid tumors. ${ }^{50-53}$

Here, we identified a novel glucocorticoid-mediated mechanism that controls growth in Leydig tumor cells. We found that a synthetic GR agonist, DEXA, is able to significantly reduce proliferation rate in a well-documented in vitro model for Leydig cell neoplasms, such as the R2C cell line. We demonstrated that DEXA treatment induces cell cycle arrest and modulates genes involved in the glucocorticoid-dependent regulation of cell growth. 
Moreover, we evidenced that the observed effects of DEXA on $\mathrm{R} 2 \mathrm{C}$ proliferation appear to be related to a reduction of local estrogen production, which represents a major feature of $\mathrm{R} 2 \mathrm{C}$ cells. ${ }^{4}$

Indeed, in R2C cells, DEXA treatment negatively affects the enzyme aromatase by decreasing its expression at both mRNA and protein levels, together with the inhibition of its enzymatic activity. Our results indicate that the downregulation of aromatase expression induced by DEXA administration strictly depends on GR activation, because it was completely reversed in the presence of the GR inhibitor RU-486.

All these findings suggest that GR-mediated inhibition of aromatase involves regulation of aromatase gene transcriptional activity; thus, we focused on the molecular mechanisms by which GR mediates repression of the aromatase enzyme. Distinctive tissue-specific aromatase promoters are used to control the expression of aromatase mRNA. The promoter located immediately upstream of the transcriptional initiation site (PII) regulates aromatase expression in rat Leydig, Sertoli, and germ cells and in R2C cells. ${ }^{34,35}$ Here, we provided evidence that activated GR is a transcriptional repressor of the aromatase gene in Leydig tumor cells. Specifically, we have demonstrated by functional studies and ChIP assays that GR-mediated inhibition of the aromatase is due to direct binding of the GR to a newly identified putative glucocorticoid responsive site within the aromatase proximal promoter. It is well known that glucocorticoids exert their effects by activating the GR, a liganddependent transcriptional regulator that transduces the hormonal signal into the nucleus to alter the expression of target genes. On glucocorticoid binding, GR undergoes conformational changes, dissociates from the heat shock proteins, homodimerizes, and translocates into the nucleus, where it binds to GREs into DNA in the promoter of target genes, resulting in stimulation or suppression of the transcription of response genes (known as transactivation or transrepression effect, respectively). ${ }^{41}$ GR can regulate transcription by several distinct mechanisms, and its function, as shown for other corticosteroid receptors, seems to depend not only on ligand binding, which is known to regulate receptor conformation, but also on the context of the gene and associated promoter factors that contribute to create a gene-specific topography, achieving specific profiles of gene expression. Indeed, the liganded GR can interact with many components of the transcriptional machinery, including coactivators, corepressors, chromatin remodeling proteins, components of the mediator complex, and RNA polymerase II and components of the basal transcriptional machinery. ${ }^{54}$ Data from ChIP analysis revealed that GR occupancy to the GRE-containing promoter region is concomitant with a decrease in RNA Pol II recruitment, consistent with the reduced aromatase transcriptional activity. GR-mediated repression of the aromatase gene involves the recruitment of the corepressors $\mathrm{NCoR}$ and SMRT, which share the same molecular architecture, interact with many of the same transcription factors, and assemble into similar corepressor complexes. ${ }^{55}$ Indeed, NCoR and SMRT are recruited by GR to regulate the transcription of different genes. ${ }^{56}$

The physiologic relevance of the inhibitory effects exerted by glucocorticoids on Leydig tumor cell growth is pointed out by our in vivo studies showing that DEXA significantly decreases the growth of R2C xenografts. Our results evidenced in tumor sections from DEXA-treated mice a marked reduction in the expression of the nuclear proliferation antigen $\mathrm{Ki}-67$ and the estrogen-producing enzyme aromatase. Importantly, DEXA administration did not affect the normal testis structure. Indeed, no significant differences were found on the histopathologic features of seminiferous tubules between vehicle-treated and DEXAtreated mice.

In conclusion, our findings suggest the possibility that targeting the GR could be helpful in improving new molecular and pharmacologic approaches for LCT treatment.

\section{Supplemental Data}

Supplemental material for this article can be found at http://dx.doi.org/10.1016/j.ajpath.2015.12.024.

\section{References}

1. Hawkins C, Miaskowski C: Testicular cancer: a review. Oncol Nurs Forum 1996, 23:1203-1211

2. Fowler KA, Gill K, Kirma N, Dillehay DL, Tekmal RR: Overexpression of aromatase leads to development of testicular leydig cell tumors: an in vivo model for hormone-mediated Testicular Cancer. Am J Pathol 2000, 156:347-353

3. Li X, Strauss L, Kaatrasalo A, Mayerhofer A, Huhtaniemi I, Santti R, Mäkelä S, Poutanen M: Transgenic mice expressing p450 aromatase as a model for male infertility associated with chronic inflammation in the testis. Endocrinology 2006, 147:1271-1277

4. Sirianni R, Chimento A, Malivindi R, Mazzitelli I, Andò S, Pezzi V: Insulin-like growth factor-I, regulating aromatase expression through steroidogenic factor 1, supports estrogen-dependent tumor Leydig cell proliferation. Cancer Res 2007, 67:8368-8377

5. Carpino A, Rago V, Pezzi V, Carani C, Andò S: Detection of aromatase and estrogen receptors (ERalpha, ERbeta1, ERbeta2) in human Leydig cell tumor. Eur J Endocrinol 2007, 157:239-244

6. Brodie A, Inkster S, Yue W: Aromatase expression in the human male. Mol Cell Endocrinol 2001, 178:23-28

7. Bulun SE, Rosenthal IM, Brodie AM, Inkster SE, Zeller WP DiGeorge AM, Frasier SD, Kilgore MW, Simpson ER: Use of tissuespecific promoters in the regulation of aromatase cytochrome P450 gene expression in human testicular and ovarian sex cord tumors, as well as in normal fetal and adult gonads. J Clin Endocrinol Metab 1994, 78:1616-1621

8. Straume AH, Løvås K, Miletic H, Gravdal K, Lønning PE, Knappskog S: Elevated levels of the steroidogenic factor 1 are associated with over-expression of CYP19 in an oestrogenproducing testicular Leydig cell tumour. Eur J Endocrinol 2012 , 166:941-949

9. Catalano S, Malivindi R, Giordano C, Gu G, Panza S, Bonofiglio D, Lanzino M, Sisci D, Panno ML, Andò S: Farnesoid X receptor, through the binding with steroidogenic factor 1-responsive element, 
inhibits aromatase expression in tumor Leydig cells. J Biol Chem 2010, 285:5581-5593

10. Catalano S, Panza S, Malivindi R, Giordano C, Barone I, Bossi G, Lanzino M, Sirianni R, Mauro L, Sisci D, Bonofiglio D, Andò S: Inhibition of Leydig tumor growth by farnesoid $\mathrm{X}$ receptor activation: the in vitro and in vivo basis for a novel therapeutic strategy. Int $\mathrm{J}$ Cancer 2013, 132:2237-2247

11. Maris P, Campana A, Barone I, Giordano C, Morelli C, Malivindi R, Sisci D, Aquila S, Rago V, Bonofiglio D, Catalano S, Lanzino M, Andò $\mathrm{S}$ : Androgens inhibit aromatase expression through DAX-1: insights into the molecular link between hormone balance and Leydig cancer development. Endocrinology 2015, 156:1251-1262

12. Ortlip SA, Li SA, Li JJ: Characterization of specific glucocorticoid receptor in the Syrian hamster testis. Endocrinology 1981, 109:1331-1338

13. Stalker A, Hermo L, Antakly T: Covalent affinity labeling, radioautography, and immunocytochemistry localize the glucocorticoid receptor in rat testicular Leydig cells. Am J Anat 1989, 186:369-377

14. Schultz R, Isola J, Parvinen M, Honkaniemi J, Wikström AC, Gustafsson JA, Pelto-Huikko M: Localization of the glucocorticoid receptor in testis and accessory sexual organs of male rat. Mol Cell Endocrinol 1993, 95:115-120

15. Bartke A: Effects of growth hormone on male reproductive functions. J Androl 2000, 21:181-188

16. Hardy MP, Gao HB, Dong Q, Ge R, Wang Q, Chai WR, Feng X, Sottas C: Stress hormone and male reproductive function. Cell Tissue Res 2005, 322:147-153

17. Gao HB, Shan LX, Monder C, Hardy MP: Suppression of endogenous corticosterone levels in vivo increases the steroidogenic capacity of purified rat Leydig cells in vitro. Endocrinology 1996, 137:1714-1718

18. Schwarzenbach H, Manna PR, Stocco DM, Chakrabarti G, Mukhopadhyay AK: Stimulatory effect of progesterone on the expression of steroidogenic acute regulatory protein in MA-10 Leydig cells. Biol Reprod 2003, 68:1054-1063

19. Martin LJ, Tremblay JJ: Glucocorticoids antagonize cAMP-induced Star transcription in Leydig cells through the orphan nuclear receptor NR4A1. J Mol Endocrinol 2008, 41:165-175

20. Hales DB, Payne AH: Glucocorticoid-mediated repression of P450scc mRNA and de novo synthesis in cultured Leydig cells. Endocrinology 1989, 124:2099-2104

21. Payne AH, Sha LL: Multiple mechanisms for regulation of 3 betahydroxysteroid dehydrogenase/delta 5-delta 4-isomerase, 17 alpha hydroxylase/C17-20 lyase cytochrome P450, and cholesterol sidechain cleavage cytochrome P450 messenger ribonucleic acid levels in primary cultures of mouse Leydig cells. Endocrinology 1991, 129: $1429-1435$

22. Badrinarayanan R, Rengarajan S, Nithya P, Balasubramanian K: Corticosterone impairs the mRNA expression and activity of 3betaand 17beta-hydroxysteroid dehydrogenases in adult rat Leydig cells. Biochem Cell Biol 2006, 84:745-754

23. Xiao YC, Huang YD, Hardy DO, Li XK, Ge RS: Glucocorticoid suppresses steroidogenesis in rat progenitor Leydig cells. J Androl 2010, 31:365-371

24. Ing NH, Forrest DW, Riggs PK, Loux S, Love CC, Brinsko SP, Varner DD, Welsh TH Jr: Dexamethasone acutely down-regulates genes involved in steroidogenesis in stallion testes. J Steroid Biochem Mol Biol 2014, 143:451-459

25. Gao HB, Tong MH, Hu YQ, Guo QS, Ge R, Hardy MP: Glucocorticoid induces apoptosis in rat leydig cells. Endocrinology 2002, 143: $130-138$

26. Catalano S, Barone I, Giordano C, Rizza P, Qi H, Gu G, Malivindi R, Bonofiglio D, Andò S: Rapid estradiol/ERalpha signaling enhances aromatase enzymatic activity in breast cancer cells. Mol Endocrinol 2009, 23:1634-1645

27. Young M, McPhaul MJ: A steroidogenic factor-1-binding site and cyclic adenosine 3',5'-monophosphate response element-like elements are required for the activity of the rat aromatase promoter in rat Leydig tumor cell lines. Endocrinology 1998, 139:5082-5093
28. Barone I, Cui Y, Herynk MH, Corona-Rodriguez A, Giordano C, Selever J, Beyer A, Andò S, Fuqua SA: Expression of the K303R estrogen receptor-alpha breast cancer mutation induces resistance to an aromatase inhibitor via addiction to the PI3K/Akt kinase pathway. Cancer Res 2009, 69:4724-4732

29. Giordano C, Cui Y, Barone I, Ando S, Mancini MA, Berno V, Fuqua SA: Growth factor-induced resistance to tamoxifen is associated with a mutation of estrogen receptor alpha and its phosphorylation at serine 305. Breast Cancer Res Treat 2010, 119:71-85

30. Catalano S, Leggio A, Barone I, De Marco R, Gelsomino L, Campana A, Malivindi R, Panza S, Giordano C, Liguaori A, Bonofiglio D, Liguori A, Andò S: A novel leptin antagonist peptide inhibits breast cancer growth in vitro and in vivo. J Cell Mol Med 2015, 19:1122-1132

31. Catalano S, Pezzi V, Chimento A, Giordano C, Carpino A, Young M, McPhaul MJ, Andò S: Triiodothyronine decreases the activity of the proximal promoter (PII) of the aromatase gene in the mouse Sertoli cell line, TM4. Mol Endocrinol 2003, 17:923-934

32. Aquila S, Sisci D, Gentile M, Carpino A, Middea E, Catalano S, Rago V, Andò S: Towards a physiological role for cytochrome P450 aromatase in ejaculated human sperm. Hum Reprod 2003, 18:1650-1659

33. Inkster S, Yue W, Brodie A: Human testicular aromatase: immunocytochemical and biochemical studies. J Clin Endocrinol Metab 1995, 80:1941-1947

34. Young M, Lephart ED, McPhaul MJ: Expression of aromatase cytochrome P450 in rat H540 Leydig tumor cells. J Steroid Biochem Mol Biol 1997, 63:37-44

35. Lanzino M, Catalano S, Genissel C, Ando S, Carreau S, Hamra K, McPhaul MJ: Aromatase messenger RNA is derived from the proximal promoter of the aromatase gene in Leydig, Sertoli, and germ cells of the rat testis. Biol Reprod 2001, 64:1439-1443

36. Ronacher K, Hadley K, Avenant C, Stubsrud E, Simons SS Jr, Louw A, Hapgood JP: Ligand-selective transactivation and transrepression via the glucocorticoid receptor: role of cofactor interaction. Mol Cell Endocrinol 2009, 299:219-231

37. Ahmed HU, Arya M, Muneer A, Mushtaq I, Sebire NJ: Testicular and paratesticular tumours in the prepubertal population. Lancet Oncol 2010, 11:476-483

38. McCluggage WG, Shanks JH, Arthur K, Banerjee SS: Cellular proliferation and nuclear ploidy assessments augment established prognostic factors in predicting malignancy in testicular Leydig cell tumours. Histopathology 1998, 33:361-368

39. Woolveridge I, Taylor MF, Rommerts FF, Morris ID: Apoptosis related gene products in differentiated and tumorigenic rat Leydig cells and following regression induced by the cytotoxin ethane dimethanesulphonate. Int J Androl 2001, 24:56-64

40. Azer PC, Braunstein GD: Malignant Leydig cell tumor: objective tumor response to o,p'-DDD. Cancer 1981, 47:1251-1255

41. Vandevyver S, Dejager L, Libert C: Comprehensive overview of the structure and regulation of the glucocorticoid receptor. Endocr Rev 2014, 35:671-693

42. Alnemri ES, Fernandes TF, Haldar S, Croce CM, Litwack G: Involvement of BCL-2 in glucocorticoid-induced apoptosis of human pre-B-leukemias. Cancer Res 1992, 52:491-495

43. Thompson EB, Thulasi R, Saeed MF, Johnson BH: Glucocorticoid antagonist RU 486 reverses agonist-induced apoptosis and c-myc repression in human leukemic CEM-C7 cells. Ann N Y Acad Sci 1995, 761:261-275

44. Buse P, Woo PL, Alexander DB, Cha HH, Reza A, Sirota ND, Firestone GL: Transforming growth factor-alpha abrogates glucocorticoid-stimulated tight junction formation and growth suppression in rat mammary epithelial tumor cells. J Biol Chem 1995, 270:6505-6514

45. Goya L, Maiyar AC, Ge Y, Firestone GL: Glucocorticoids induce a G1/G0 cell cycle arrest of Con8 rat mammary tumor cells that is synchronously reversed by steroid withdrawal or addition of transforming growth factor-alpha. Mol Endocrinol 1993, 7:1121-1132 
46. Frost GH, Rhee K, Ma T, Thompson EA: Expression of c-Myc in glucocorticoid-treated fibroblastic cells. J Steroid Biochem Mol Biol 1994, 50:109-119

47. Sánchez I, Goya L, Vallerga AK, Firestone GL: Glucocorticoids reversibly arrest rat hepatoma cell growth by inducing an early G1 block in cell cycle progression. Cell Growth Differ 1993, 4: $215-225$

48. Takayama S, Rogatsky I, Schwarcz LE, Darimont BD: The glucocorticoid receptor represses cyclin D1 by targeting the Tcf- $\beta$-catenin complex. J Biol Chem 2006, 281:17856-17863

49. Chebotaev D, Yemelyanov A, Budunova I: The mechanisms of tumor suppressor effect of glucocorticoid receptor in skin. Mol Carcinog 2007, 46:732-740

50. Yemelyanov A, Czwornog J, Chebotaev D, Karseladze A, Kulevitch E, Yang X, Budunova I: Tumor suppressor activity of glucocorticoid receptor in the prostate. Oncogene 2007, 26:1885-1896

51. Gaynon PS, Lustig RH: The use of glucocorticoids in acute lymphoblastic leukemia of childhood. Molecular, cellular, and clinical considerations. J Pediatr Hematol Oncol 1995, 17:1-12
52. Pirotte B, Levivier M, Goldman S, Brucher JM, Brotchi J, Hildebrand J: Glucocorticoid-induced long-term remission in primary cerebral lymphoma: case report and review of the literature. J Neurooncol 1997, 32:63-69

53. Karmakar S, Jin Y, Nagaich AK: Interaction of glucocorticoid receptor (GR) with estrogen receptor (ER) $\alpha$ and activator protein 1 (AP1) in dexamethasone-mediated interference of ER $\alpha$ activity. J Biol Chem 2013, 288:24020-24034

54. Kumar R, Thompson EB: Gene regulation by the glucocorticoid receptor: structure:function relationship. J Steroid Biochem Mol Biol 2005, 94:383-394

55. Ghisletti S, Huang W, Jepsen K, Benner C, Hardiman G, Rosenfeld MG, Glass CK: Cooperative NCoR/SMRT interactions establish a corepressor-based strategy for integration of inflammatory and antiinflammatory signaling pathways. Genes Dev 2009, 23:681-693

56. Wang Q, Blackford JA Jr, Song LN, Huang Y, Cho S, Simons SS Jr: Equilibrium interactions of corepressors and coactivators with agonist and antagonist complexes of glucocorticoid receptors. Mol Endocrinol 2004, 18:1376-1395 